\title{
Motivasi Pengrajin Industri Rumah Tangga dalam Menabung Di Bank di Kecamatan Amuntai Tengah Kabupaten Hulu Sungai Utara
}

\section{(Household Industry Crafts Motivation Saving at Banks In Amuntai Tengah District Hulu Sungai Utara Regency)}

\author{
Rum Van Royensyah ${ }^{1)}$ \& Yunita ${ }^{2)}$ \\ ${ }^{1)}$ Program Studi Agribisnis, Sekolah Tinggi Ilmu Pertanian Amuntai \\ ${ }^{1)}$ Vanroyensyah61@gmail.com \\ ${ }^{2)}$ ynt@yahoo.com
}

\begin{abstract}
ABSTRAK
Penelitian ini bertujuan untuk mengetahui tingkat faktor yang mempengaruhi motivasi pengrajin, tingkat motivasi pengrajin dan hubungan antara tingkat faktor-faktor yang mempengaruhi motivasi pengrajin industri rumah tangga dalam menabung dibank. Penelitian ini dilaksanakan di Kecamatan Amuntai Tengah Kabupaten Hulu Sungai Utara. Berdasarkan hasil penelitian menyatakan bahwa pada uji $F$ secara bersama-sama faktor-faktor yang mempengaruhi motivasi berpengaruh signifikan terhadap motivasi pengrajin industri rumah tangga dalam menabung di bank, sedangkan pada uji t secara parsial hanya ketersediaan sarana produksi yang berpengaruh nyata terhadap motivasi pengrajin dalam menabung di bank. Sedangkan hubungan faktor-faktor yang mempengaruhi motivasi pengrajin adalah variabel tingkat pendidikan dan variabel ketersediaan sarana produksi yang terdapat hubungan yang signifikan karena nilai nilai rs sebesar 0,254 dengan sig 0,012<0,05 dan -0, 274 dengan sig 0,0007<0,05. Pada variabel umur, luas bangunan, pendapatan, ketersediaan tempat menabung dan jaminan pasar tidak terdapat hubungan yang signifikan karena nilai sig masing-masing variabel>0,05.
\end{abstract}

Kata Kunci: Motivasi, pengrajin, faktor-faktor, industry, rumah tangga.

\section{ABSTRACT}

This study aims to determine the level of factors that influence the motivation of craftsmen, the level of motivation of craftsmen and the relationship between the level of factors that influence the motivation of home industry craftsmen in saving money in the bank. This research was conducted in Amuntai Tengah District, Hulu Sungai Utara Regency. Based on the results of the study stating that the $F$ test together the factors that influence motivation significantly influence the motivation of home industry craftsmen in saving at the bank, while the t test partially only the availability of production facilities that have a significant effect on the motivation of craftsmen in saving at bank. While the relationship of factors that influence the motivation of craftsmen is the education level variable and the availability of production facilities variables that have a significant relationship because the value of rs is 0.254 with sig $0.012<0.05$ and -0, 274 with sig $0.0007<0.05$. In the age variable, building area, income, availability of saving places and market guarantees there is no significant relationship because the sig value of each variable is $>0.05$.

Keywords: Motivation, craftsmen, factors, industry, household.

\section{PENDAHULUAN}

Pertumbuhan ekonomi di era globalisasi salah satunya ditandai dengan semakin berkembangnya segala bidang usaha termasuk industri kecil atau industri rumah tangga. Perkembangan industri rumah tangga di Indonesia sekarang ini semakin meningkat sehingga mempunyai peranan yang besar dalam pembangunan perekonomian. Meningkatnya industri rumah tangga menyebabkan pendapatan pengrajin menjadi meningkat dan mendorong untuk menyisihkan sebagian penghasilan untuk ditabung di bank (BI, 2015).

Di Kabupaten Hulu Sungai Utara saat in sektor keuangan terjadi perkembangan yang sangat pesat, hal ini menggambarkan perekonomian daerah Kabupaten Hulu Sungai Utara sangat dinamis dan bergerak sangat baik sehingga bank-bank juga 
semakin berkembang. Kabupaten Hulu Sungai Utara merupakan salah satu daerah yang memberdayakan industri rumah tangga dalam pembangunan daerah.

Kecamatan Amuntai Tengah sudah banyak terdapat bank merupakan salah satu tempat menyimpan uang bagi pengrajin industri rumah tangga yang memiliki peran yang cukup besar dalam usaha-usaha kecil seperti industri rumah tangga yang ada di Kecamatan Amuntai Tengah. Kecamatan Amuntai Tengah merupakan kawasan industri rumah tangga yang paling luas. Industri yang dapat dihasilkan adalah berbagai macam kerajinan atau makanan khas daerah yang semakin berkembang (Disparindagkop. HSU, 2015).

Usaha kecil adalah kegiatan ekonomi rakyat yang beskala kecil, dan memenuhi kriteria kekayaan bersih atau hasil penjualan tahunan serta kepemilikan sebagaimana diatur dalam undang-undang. Kegiatan ekonomi rakyat yang berskala kecil adalah kegiatan ekonomi yang dimiliki dan menghidupi sebagian besar rakyat (Tohar, 1999).

Pengrajin sebagai pengelola usahanya mempunyai motivasi untuk mengembangkan usahanya. Hal ini dapat dilihat dari peran Pemerintah atau Dinas Perindustrian dan Perdagangan Kabupaten Hulu Sungai Utara yang selalu memberi arahan, pelatihan dan inovasi kepada pengrajin. Pengrajin industri rumah tangga di Kecamatan Amuntai Tengah Kabupaten Hulu Sungai Utara ini kurang termotivasi dalam menabung di bank sehingga menarik untuk diteliti karena kurangnya informasi dan pengetahuan pengrajin dalam menabung di Bank.

Tujuan penelitian ini mengkaji tingkat faktor-faktor yang mempengaruhi motivasi pengrajin industri rumah tangga (home industy) dalam menabung di Bank di Kecmataan Amuntai Tengah Kabupten Hulu Sungai Utara, (ii) tingkat motivasi pengrajin industri rumah tangga (home industry) dalam menabung di Bank di Kecamatan Amuntai Tengah Kabupaten Hulu Sungai Utara dan (iii) mengkaji hubungan antara tingkat faktor-faktor yang mempengaruhi motivasi dengan tingkat motivasi pengrajin industri rumah tangga (home industry) dalam menabung di Bank di Kecamatan Amuntai Tengah Kabupaten Hulu Sungai Utara.

\section{METODE PENELITIAN}

\section{Lokasi dan Waktu Penelitian}

Penelitian ini dilaksanakan di Kecamatan Amuntai Tengah Kabupaten Hulu Sungai Utara. Waktu penelitian dimulai dari bulan Maret - Juni 2016.

\section{Jenis Data dan Sumber Data}

Jenis dan sumber data yang digunakan dalam penelitian ini adalah data primer yang diperoleh secara langsung dari pengrajin industri rumah tangga (home industry) dengan menggunakan kuesioner (angket) yang telah disiapkan dan wawancara dengan pemilik industri rumah tangga dan data sekunder yang digunakan dalam penelitian ini diperoleh dari berbagai buku, skripsi, internet dan instansi terkait yang berhubungan dengan penelitian yang dilakukan.

\section{Metode Pengumpulan Data}

Metode pengumpulan data yang digunakan dalam penelitian ini dilakukan dengan Sampel Bertingkat (Multi Stage Sampling) dan menggunakan teknik Accidential Sampling.

\section{Analisis Data}

Variabel bebas yang mempengaruhi bersifat kuantitatif dan kualitatif sekaligus. Sehingga digunakanlah analisis regresi dengan variabel kuantitatif dan kualitatif. Adapun yang menjadi variabel pada penelitian ini yaitu terdiri atas variabel bebas (independen), yang meliputi umur $\left(\mathrm{X}_{1}\right)$, tingkat pendidikan $\left(\mathrm{X}_{2}\right)$, luas bangunan $\left(\mathrm{X}_{3}\right)$, pendapatan $\left(\mathrm{X}_{4}\right)$, menabung di bank $\left(\mathrm{X}_{5}\right)$, ketersediaan sarana produksi $\left(\mathrm{X}_{6}\right)$, dan adanya jaminan pasar $\left(\mathrm{X}_{7}\right)$. Sedangkan variabel terikat (dependen) adalah motivasi pengrajin(Y). Dengan metode analisis ini dapat diketahui/diprediksi adanya pengaruh motivasi pengrajin industri rumah tangga dalam menabung di bank di Kecamatan 
Amuntai Tengah Kabupaten Hulu Sungai Utara.

Pengukuran motivasi pengrajin menggunakan skala Likert yaitu pada variabel motivasi ekonomi dan motivasi sosiologis untuk mengukur tanggapan atau respon responden.

Hubungan antara faktor-faktor yang mempengaruhi dengan tingkat motivasi pengrajin dalam menabung di bank di Kecamatan Amuntai Tengah maka digunakan analisis korelasi untuk mencari keeratan hubungan antara dua variabel.

\section{HASIL DAN PEMBAHASAN}

Tabel 1. Jumlah skor jawaban dari pernyataan responden pengrajin

\begin{tabular}{cccccccccc}
\hline Pernyataan & 1 & 2 & 3 & 4 & 5 & 6 & 7 & Total & Rata-rata \\
\hline $\begin{array}{c}\text { Jumlah total } \\
\text { frekuensi } \\
\text { (orang) x skor }\end{array}$ & 296 & 358 & 287 & 260 & 308 & 299 & 308 & 2.116 & 302,28 \\
\hline
\end{tabular}

Hasil pengukuran tingkat motivasi pengrajin dengan menggunakan skala likert adalah sebagai berikut:

\begin{tabular}{|c|c|c|c|c|c|c|}
\hline Negatif & STS & $\mathrm{TS}$ & $\mathrm{RG}$ & $\mathbf{3 0 2 , 2 8} \mathrm{S}$ & SS & Positif \\
\hline & 80 & 160 & $24 b$ & 320 & 400 & \\
\hline
\end{tabular}

\section{Uji F}

Uji $F$ digunakan untuk menunjukan apakah semua variabel independen yang dimasukan dalam model memiliki pengaruh

\section{Motivasi Pengrajin Industri Rumah Tangga dalam Menabung di Bank}

Motivasi pengrajin diartikan sebagai suatu kondisi yang mendorong seseorang untuk melaksanakan suatu tindakan dalam rangka mencapai tujuannya. Motivasi ini diukur dengan menggunakan penyataanpernyataan positif dan negatif. Motivasi petani berdasarkan responden yang mengisi kuisioner yang diberikan dengan cara menghitung jumlah total frekuensi (orang) dikali dengan nilai skor seperti pada Tabel 1 berikut.

Tabel 2. Hasil Uji F terhadap variabel bebas

\begin{tabular}{cccccc}
\hline Model & Sum of Squares & df & $\begin{array}{c}\text { Mean } \\
\text { Square }\end{array}$ & F Hitung & Sig. \\
\hline Regression & 486,905 & 7 & 69,558 & 2,192 &, $045^{\text {b }}$ \\
Residual & 2284,895 & 72 & 31,735 & & \\
\hline Total & 2771,800 & 79 & & & \\
\hline
\end{tabular}

Sumber: Hasil pengolahan data primer (2016)

Dari tabel di atas terlihat bahwa nilai FHitung sebesar 2,192 dengan nilai signifikan $F$ sebesar 0,045. Nilai $F_{\text {tabel }}$ dengan tingkat kepercayaan $95 \%(\alpha=5 \%)$ dengan nilai $\mathrm{dfl}=$ 7 dab df $2=72$ sehingga nilai $F_{\text {tabel }}$ sebesar 2,231. Dari hasil tersebut dapat disimpulkan bahwa nilai $F_{\text {Hitung }}(2,192)$ lebih kecil dari secara bersama-sama terhadap variabel dependen. Hasil uji $\mathrm{F}$ dapat dilihat melalui nilai $\mathrm{F}$ hitung dan nilai signifikan $\mathrm{F}$ pada Tabel 1 berikut ini.
$F_{\text {tabel }}(2,231)$ dengan tingkat signifikasi juga lebih kecil dari 0,05.

Nilai signifikan F sebesar 0,045 $<0,05$ sehingga $\mathrm{H}_{0}$ ditolak dan $\mathrm{H}_{1}$ diterima. Artinya variabel umur, tingkat pendidikan, luas bangunan, pendapatan, ketersediaan tempat menabung, ketersediaan sarana produksi, dan jaminan pasar secara bersama- 
sama berpengaruh nyata terhadap motivasi pengrajin industri rumah tangga dalam menabung di bank.

\section{Uji Individual (Uji t)}

Untuk mengetahui apakah variabelvariabel independen dapat mempengaruhi variabel dependen, oleh karena itu diperlukan pengujian statistik secara parsial.
Dengan dilakukannya uji t ini maka akan diketahui apakah faktor umur, tingkat pendidikan, luas bangunan, pendapatan, menabung di bank, ketersediaan sarana produksi, dan adanya jaminan pasar secara parsial berpengaruh nyata terhadap motivasi pengrajin industri rumah tangga. Adapun hasil uji t tersebut dapat dilihat pada Tabel 3.

Tabel 3. Hasil uji t terhadap variabel bebas

\begin{tabular}{lcc}
\hline \multicolumn{1}{c}{ Variabel } & $\mathrm{T}_{\text {hitung }}$ & Signifikan \\
\hline Umur $\left(\mathrm{X}_{1}\right)$ & 0,700 & 0,486 \\
Tingkat Pendidikan $\left(\mathrm{X}_{2}\right)$ & 1,779 & 0,080 \\
Luas Bangunan $\left(\mathrm{X}_{3}\right)$ & $-1,341$ & 0,184 \\
Pendapatan $\left(\mathrm{X}_{4}\right)$ & $-1,119$ &, 267 \\
Ketersediaan Tempat Menabung $\left(\mathrm{X}_{5}\right)$ & $-0,140$ &, 889 \\
Ketersediaan Sarana Produksi $\left(\mathrm{X}_{6}\right)$ & $-3,087$ & 0,003 \\
Jaminan Pasar $\left(\mathrm{X}_{7}\right)$ & $-0,311$ & 0,757 \\
\hline
\end{tabular}

Sumber: Hasil pengolahan data primer (2016).

Berdasarkan hasil uji t yang terdapat pada tabel di atas didapat bahwa nilai $T_{\text {hitung }}$ untuk variabel umur sebesar 0,700 lebih kecil dari nilai $\mathrm{T}_{\text {tabel }}(1,664)$ dengan nilai signifikan $\mathrm{t} 0,486>0,05$ sehingga $\mathrm{H}_{0}$ diterima dan $\mathrm{H}_{1}$ ditolak. Artinya secara parsial variabel umur tidak berpengaruh bermakna terhadap motivasi pengrajin industri rumah tangga dalam menabung di bank.

Hasil pengujian uji statistik $\mathrm{t}$ pada variabel tingkat pendidikan menunjukan bahwa nilai $\mathrm{T}_{\text {hitung }}$ sebesar 1,779 dan $\mathrm{T}_{\text {tabel }}$ sebesar 1,664 ( $\left.\mathrm{T}_{\text {hitung }}>\mathrm{T}_{\text {tabel }}\right)$ dengan tingkat signifikan $0,080>0,05$. Sehingga dapat disimpulkan bahwa $\mathrm{H}_{0}$ diterima dan $\mathrm{H}_{1}$ ditolak. Artinya secara parsial variabel tingkat pendidikan tidak berpengaruh bermakna terhadap motivasi pengrajin industri rumah tangga dalam menabung di bank.

Pada hasil pengujian uji statistik t pada luas bangunan menunjukan bahwa nilai

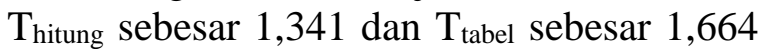
( $\left.\mathrm{T}_{\text {hitung }}<\mathrm{T}_{\text {tabel }}\right)$ dengan tingkat signifikan $0,184>0,05$. Sehingga dapat disimpulkan bahwa $\mathrm{H}_{0}$ diterima dan $\mathrm{H}_{1}$ ditolak. Artinya secara parsial variabel luas bangunan tidak berpengaruh bermakna terhadap motivasi pengrajin industri rumah tangga dalam menabung di bank.

Sedangkan pada variabel pendapatan didapat nilai $\mathrm{T}_{\text {hitung }}$ sebesar $1,119 \mathrm{~T}_{\text {tabel }}$ sebesar 1,664 ( $\left.\mathrm{T}_{\text {hitung }}<\mathrm{T}_{\text {tabel }}\right)$ dengan tingkat signifikasi t sebesar $0,267>0,05$. Sehingga dapat disimpulkan bahwa $\mathrm{H}_{0}$ diterima dan $\mathrm{H}_{1}$ ditolak. Artinya secara parsial variabel pendapatan tidak berpengaruh bermakna terhadap motivasi pengrajin industri rumah tangga dalam menabung di bank.

Nilai $T_{\text {hitung }}$ untuk variabel ketersediaan tempat menabung sebesar 0,140 lebih kecil dari nilai $\mathrm{T}_{\text {tabel }}(1,664)$ dengan nilai signifikan $\mathrm{t} 0,889>0,05$, sehingga $\quad \mathrm{H}_{0}$ diterima dan $\mathrm{H}_{1}$ ditolak. Artinya secara parsial ketersediaan tempat menabung tidak berpengaruh bermakna terhadap motivasi pengrajin industri rumah tangga dalam menabung di bank.

Hasil pengujian uji statistik $\mathrm{t}$ pada variabel ketersediaan sarana produksi menunjukan bahwa nilai $T_{\text {hitung }}$ sebesar 3,087 dan $\mathrm{T}_{\text {tabel }}$ sebesar 1,664 $\left(\mathrm{T}_{\text {hitung }}>\right.$ $\mathrm{T}_{\text {tabel }}$ ) dengan tingkat signifikan $0,003<$ 0,05. Sehingga dapat disimpulkan bahwa $\mathrm{H}_{0}$ ditolak dan $\mathrm{H}_{1}$ diterima. Artinya secara parsial variabel ketersediaan sarana produksi berpengaruh bermakna terhadap motivasi 
pengrajin industri rumah tangga dalam menabung di bank.

Sedangkan pada variabel jaminan pasar didapat nilai $\mathrm{T}_{\text {hitung }}$ sebesar $0,311 \mathrm{~T}_{\text {tabel }}$ sebesar 1,664 ( $\mathrm{T}_{\text {hitung }}<\mathrm{T}_{\text {tabel }}$ ) dengan tingkat signifikasi t sebesar 0,757>0,05. Sehingga dapat disimpulkan bahwa $\mathrm{H}_{0}$ diterima dan $\mathrm{H}_{1}$ ditolak. Artinya secara parsial variabel jaminan pasar tidak berpengaruh bermakna terhadap motivasi pengrajin industri rumah tangga dalam menabung di bank.

\section{Model Regresi Berganda Motivasi Pengrajin Industri Rumah Tangga Dalam Menabung Di Bank}

Berdasarkan hasil perhitungan statistik, maka model regresi yang didapat pada motivasi pengrajin industri rumah tangga dalam menabung di bank adalah sebagai

Tabel 4. Model Regresi Berganda Motivasi Pengrajin Industri Rumah Tangga dalam Menabung di Bank

\begin{tabular}{lcccc}
\hline \multicolumn{1}{c}{ Variabel bebas } & $\begin{array}{c}\text { Koefisien } \\
\text { Regresi }\end{array}$ & Std error & THitung & Sig. \\
\hline Konstanta & 25,427 & 6,222 & 4,087 &, 000 \\
Umur &, 061 &, 087 &, 700 &, 486 \\
Tingkat Pendidikan & 3,627 & 2,039 & 1,779 &, 080 \\
Luas Bangunan &,- 030 &, 023 & $-1,341$ &, 184 \\
Pendapatan & $-1,612$ & 1,441 & $-1,119$ &, 267 \\
Ketersediaan tempat Menabung &,- 303 & 2,157 &,- 140 &, 889 \\
Ketersediaan Sarana Produksi & $-4,040$ & 1,309 & $-3,087$ &, 003 \\
Jaminan Pasar &,- 454 & 1,458 &,- 311 &, 757 \\
\hline
\end{tabular}

Sumber: Hasil Pengolahan Data Primer (2016).

Berdasarkan hasil analisis regresi pada tabel tersebut, dapat diperoleh model regresi linier berganda sebagai berikut:

$$
\begin{aligned}
\mathrm{Y}= & 25,427+0,061 \mathrm{X}_{1}+3,627 \mathrm{X}_{2}-0,030 \mathrm{X}_{3} \\
& -1,612 \mathrm{X}_{4}-0,303 \mathrm{X}_{5}-4,040 \mathrm{X}_{6} \\
& +0,454 \mathrm{X}_{7}
\end{aligned}
$$

Model tersebut dapat dijelaskan sebagai berikut:

Koefisien regresi umur sebesar 0,061 menunjukan bahwa setiap kenaikan satu satuan umur akan meningkatkan motivasi pengrajin dalam menabung di bank sebesar Rp. 0,061. Koefisien regresi tingkat pendidikan sebesar 3,627 menunjukan bahwa setiap kenaikan satu satuan tingkat pendidikan akan meningkatkan motivasi pengrajin dalam menabung di bank sebesar Rp. 3,627. Koefisien regresi luas bangunan sebesar -0,030 menunjukan bahwa setiap kenaikan satu satuan luas bangunan akan meningkatkan motivasi pengrajin dalam menabung di bank sebesar Rp. -0,030. Koefisien regresi pendapatan sebesar $-1,612$ menunjukan bahwa setiap kenaikan satu satuan pendapatan akan meningkatkan motivasi pengrajin dalam menabung di bank sebesar Rp. -1,612. Koefisien regresi ketersediaan tempat menabung sebesar 0,303 menunjukan bahwa setiap kenaikan satu satuan ketersediaan tempat menabung akan meningkatkan motivasi pengrajin dalam menabung di bank sebesar Rp. 0,303. Koefisien regresi ketersediaan sarana produksi sebesar $-4,040$ menunjukan bahwa setiap kenaikan satu satuan ketersediaan sarana produksi akan meningkatkan motivasi pengrajin dalam menabung di bank sebesar Rp. -4,040. Koefisien regresi jaminan pasar sebesar 0,454 menunjukan bahwa setiap kenaikan satu satuan jaminan pasar akan meningkatkan motivasi pengrajin dalam menabung di bank sebesar Rp. 0,454.

Hubungan Antara Tingkat Faktor-Faktor yang Mempengaruhi Motivasi Pengrajin dengan Tingkat Motivasi Pengrajin dalam Menabung di Bank

Guna mengetahui hubungan antara tingkat faktor-faktor yang mempengaruhi 
motivasi pengrajin dengan tingkat motivasi pengrajin dalam menabung di bank digunakan uji korelasi Rank Spearman (rs), sedangkan untuk menguji tingkat signifikansi terhadap nilai yang diperoleh dengan menggunakan besarnya nilai $\mathrm{t}_{\mathrm{Hitung}}$ dan $\mathrm{t}_{\text {Tabel }}$ dengan tingkat kepercayaan $95 \%$ $(=0,05)$. Hasil analisisnya dapat dilihat sebagai berikut:

Tabel 5. Hubungan Antara Tingkat Faktor-Faktor yang Mempengaruhi Motivasi Pengrajin dengan Tingkat Motivasi Pengrajin dalam Menabung di Bank

\begin{tabular}{lcc}
\hline \multicolumn{1}{c}{$\begin{array}{c}\text { Faktor-faktor mempengaruhi } \\
\text { motivasi }\end{array}$} & \multicolumn{2}{c}{ Tingkat Motivasi } \\
\hline Umur & $-0,014$ & 0,452 \\
Tingkat Pendidikan & 0,254 & 0,012 \\
Luas Bangunan & $-0,141$ & 0,106 \\
Pendapatan & $-0,171$ & 0,065 \\
Ketersediaan tempat Menabung & $-0,029$ & 0,399 \\
Ketersediaan Sarana Produksi & $-0,274$ & 0,007 \\
Jaminan Pasar & $-0,035$ & 0,380 \\
\hline
\end{tabular}

Sumber: Hasil Pengolahan Data Primer (2016).

Berdasarkan Tabel 5 dapat diketahui bahwa tidak terdapat hubungan yang signifikan antara umur dengan motivasi pengrajin dengan nilai rs sebesar $-0,014$ dengan nilai signifikan $0,452>0,05$. Terdapat hubungan yang signifikan antara tingkat pendidikan dengan motivasi pengrajin dengan nilai rs sebesar 0,254 dengan nilai signifikan $0,012<0,05$. Tidak terdapat hubungan yang signifikan antara luas bangunan dengan motivasi pengrajin dengan nilai rs sebesar $-0,141$ dengan nilai signifikan $0,106>0,05$. Tidak terdapat hubungan yang signifikan antara pendapatan dengan motivasi pengrajin dengan nilai rs sebesar $-0,171$ dengan nilai signifikan $0,065>0,05$. Tidak terdapat hubungan yang signifikan antara ketersediaan tempat menabung dengan motivasi pengrajin dengan nilai rs sebesar 0,029 dengan nilai signifikan $0,399>0,05$. Terdapat hubungan yang signifikan antara ketersediaan sarana produksi dengan motivasi pengrajin dengan nilai rs sebesar 0,274 dengan nilai signifikan $0,007<0,05$. Tidak terdapat hubungan yang signifikan antara jaminan pasar dengan motivasi pengrajin dengan nilai rs sebesar $-0,035$ dengan nilai signifikan $0,380>0,05$.

\section{Pembahasan}

\section{Tingkat $\quad$ Faktor-faktor yang Mempengaruhi Motivasi Pengrajin dalam Menabung di Bank}

Berdasarkan tabel uji $F$ tersebut diketahui bahwa nilai $F_{\text {Hitung }}(2,192)$ lebih kecil dari $F_{\text {tabel }}(2,231)$ dengan tingkat signifikasi juga lebih kecil dari 0,05. Nilai signifikan $\mathrm{F}$ sebesar $0,045<0,05$ sehingga $\mathrm{H}_{0}$ ditolak dan $\mathrm{H}_{1}$ diterima. Artinya variabel umur, tingkat pendidikan, luas bangunan, pendapatan, ketersediaan tempat menabung, ketersediaan sarana produksi, dan jaminan pasar secara bersama-sama berpengaruh nyata terhadap motivasi pengrajin industri rumah tangga dalam menabung di bank.

Umur

Hasil uji t yang terdapat pada Tabel 3 didapat bahwa secara parsial variabel umur tidak berpengaruh nyata terhadap motivasi pengrajin industri rumah tangga dalam menabung di bank disebabkan karena pengrajin yang berumur tua ataupun muda sama-sama memiliki motivasi.

Tingkat Pendidikan

Hasil pengujian uji statistik $\mathrm{t}$ pada variabel tingkat pendidikan menunjukan secara parsial variabel tingkat pendidikan tidak berpengaruh nyata terhadap motivasi pengrajin industri rumah tangga dalam menabung di bank karena motivasi dalam menabung di bank tidak didasarkan atas tingkat pendidikan dan tidak mempengaruhi 
tingkat kecepatan pengrajin dalam menerima saran dalam menabung.

Luas Bangunan

Berdasarkan hasil pengujian uji statistik t pada luas bangunan menunjukan bahwa secara parsial variabel luas bangunan tidak berpengaruh nyata terhadap motivasi pengrajin industri rumah tangga dalam menabung di bank disebabkan karena ukuran bangunan tidak mempengaruhi pendapatan pengrajin.

Pendapatan

Berdasarkan hasil pengujian uji statistik t secara parsial variabel pendapatan tidak berpengaruh nyata terhadap motivasi pengrajin industri rumah tangga dalam menabung di bank karena $73,75 \%$ pendapatan pengrajin dalam setahun berada pada kategori > Rp. 50.000.000 sehingga hanya cukup untuk kebutuhan hidup dan sebagai modal usaha.

Ketersediaan Tempat Menabung

Berdasarkan hasil pengujian uji statistik t secara parsial ketersediaan tempat menabung tidak berpengaruh nyata terhadap motivasi pengrajin industri rumah tangga dalam menabung di bank disebabkan pengrajin lebih memilih untuk menabung di rumah.

Ketersediaan Sarana Produksi

Hasil pengujian uji statistik $\mathrm{t}$ pada variabel ketersediaan sarana produksi menunjukan bahwa secara parsial variabel ketersediaan sarana produksi berpengaruh nyata terhadap motivasi pengrajin industri rumah tangga dalam menabung di bank karena semakin besar ketersediaan sarana produksi semakin besar motivasi pengrajin dalam melakukan usaha sehingga pendapatan yang diterima pengrajin semakin meningkat. Usaha pengrajin industri rumah tangga tergantung dari tersedianya input produksi.

Jaminan Pasar

Berdasarkan hasil pengujian uji statistik $\mathrm{t}$ secara parsial variabel jaminan pasar tidak berpengaruh nyata terhadap motivasi pengrajin industri rumah tangga dalam menabung di bank disebabkan pengrjin hanya memiliki beberapa pelanggan sehingga penjualan yang diharapkan untuk mencapai target pendapatan terhambat.

\section{Tingkat Motivasi Pengrajin Industri Rumah Tangga dalam Menabung di Bank}

Hasil pengukuran tingkat motivasi pengrajin adalah dengan menggunakan skala Likert. Hasil tersebut menjelaskan bahwa tingkat motivasi pengrajin industri rumah tangga dalam menabung di bank adalah setuju, jumlah skor rata-rata adalah 302,28 yang berada pada daerah setuju.

Hubungan Faktor-faktor yang Mempengaruhi Motivasi dengan Motivasi Pengrajin Industri Rumah Tangga dalam Menabung di Bank

Berdasarkan Tabel 5 diketahui bahwa tidak terdapat hubungan yang signifikan antara umur dengan motivasi pengrajin. Hubungan yang tidak signifikan ini terjadi karena pengrajin yang berumur muda atau tua tidak memiliki perbedaan motivasi menabung. Usaha kerajinan tidak terlalu sulit bagi pengrajin yang sudah mahir dalam melakukannya sehingga bisa diusahakan oleh pengrajin yang berumur muda ataupun yang sudah tua ; terdapat hubungan yang signifikan antara tingkat pendidikan dengan motivasi pengrajin karena tingkat pendidikan mempengaruhi pola pikir pengrajin untuk memutuskan memiliki tabungan masa depan; tidak terdapat hubungan yang signifikan antara luas bangunan dengan motivasi pengrajin. Hal tersebut disebabkan pengrajin yang memiliki bangunan luas atau sempit tetap bisa melakukan usaha kerajinan. Pembuatan kerajinan dapat dilakukan di bangunan yang sempit ataupun bangunaan yang luas; tidak terdapat hubungan yang signifikan antara pendapatan dengan motivasi pengrajin dalam membina hubungan dengan orang lain tidak perlu melihat dari pendapatan yang diperoleh seseorang dan menabung di bank bisa siapa saja, baik itu pengrajin dengan pendapatan rendah atau tinggi; tidak terdapat hubungan yang signifikan antara ketersediaan tempat menabung dengan motivasi pengrajin disebabkan pengrajin beranggapan lebih baik menabung di rumah 
karena uang yang ditabung tidak terlalu besar jumlahnya; terdapat hubungan yang signifikan antara ketersediaan sarana produksi dengan motivasi pengrajin karena adanya ketersediaan sarana produksi memudahkan pengrajin memperoleh bahan baku dan alat yang digunakan. Kemudahan dalam mempereoleh sarana produksi akan meberikan motivasi kepada pengrajin untuk menambung di bank; tidak terdapat hubungan yang signifikan antara jaminan pasar dengan motivasi pengrajin disebabkan adanya jaminan pasar ini tidak membantu pengrajin untuk memperoleh harga yang sesuai sehingga tidak mempengaruhi motivasi pengrajin dalam menabung di bank. Pemasaran di sini juga hanya sekedar penjual menawarkan kepada pembeli dengan harga yang telah ditetapkan. Meskipun ada tawar menawar dengan penjual, penentuan harga ditentukan oleh penjual. Harga hasil industri rumah tangga hanya disesuaikan dengan harga yang sedang berlaku sehingga kegiatan interaksi antar pedagang hanya sedikit. Hubungan sosial yang terjadi antar peengrajin dan pembeli juga hanya sebatas hal itu saja.

Hubungan antara tingkat faktorfaktor yang mempengaruhi motivasi pengrajin dengan tingkat motivasi pengrajin dalam menabung di bank terdapat hasil uji Rank Spearman yang positif dan negatif, berarti hubungan yang dihasilkan berbanding terbalik. Apabila faktor-faktor yang mempengaruhi motivasi pengrajin tinggi maka tingkat motivasi akan rendah dan sebaliknya jika faktor-faktor yang mempengaruhi motivasi pengrajin rendah maka tingkat motivasi pengrajin tinggi. Variabel ketersediaan sarana produksi memiliki hubungan dengan tingkat motivasi pengrajin dalam menabung di bank tetapi hasil dari Rank Spearman negatif yaitu -0 , 274, berarti hubungan yang dihasilkan tersebut berbanding terbalik. Menurut Dewandini (2010) Berdasarkan uji korelasi Rank Spearman pada taraf kepercayaan 95\% untuk Motivasi Petani Dalam Budidaya tanaman Mendong (Fimbristylis globulosa) Di Kecamatan Minggir Kabupaten Sleman menunjukan adanya hubungan yang signifikan antara tingkat pendidikan non formal, tingkat ketersediaan sarana produksi, dan tingkat kesesuaian potensi lahan dengan motivasi petani. Namun, tidak ada hubungan yang signifikan antara umur, tingkat pendidikan formal, tingkat luas penguasaan lahan, tingkat pendapatan, tingkat ketersediaan kredit usahatani, tingkat adanya jaminan pasar, tingkat ketahanan terhadap resiko, tingkat penghematan waktu budidaya, dan tingkat kesesuaian budaya setempat dengan motivasi petani.

\section{KESIMPULAN}

Hasil penelitian menyatakan bahwa pada uji $\mathrm{F}$ secara bersama-sama faktorfaktor yang mempengruhi motivasi berpengaruh signifikan terhadap motivasi pengrajin industri rumah tangga dalam menabung di bank, sedangkan pada uji $t$ secara parsial hanya ketersediaan sarana produksi yang berpengaruh nyata terhadap motivasi pengrajin dalam menabung di bank.Berdasarkan penggambaran secara kontinu diatas maka dijelaskan bahwa tingkat motivasi pengrajin industri rumah tangga dalam menabung di Kecamatan Amuntai Tengah Kabupaten Hulu Sungai Utara adalah netral tidak menilai positif atau negatif, jumlah skor rata-rata 302,28 yang berada pada daerah ragu-ragu dan setuju. Hubungan antara tingkat faktor-faktor yang mempengaruhi motivasi pengrajin dengan tingkat motivasi pengrajin indsutri rumah tangga dalam menabung di bank hanya tingkat pendidikan dan ketersediaan sarana produksi yang berhubungan signifikan. Sedangkan umur, luas bangunan, pendapatan, ketersediaan temat menabung dan jaminan pasar tidk terdapat hubungan yang signifikan terhadap motivasi pengrajin industri rumah tangga dalam menabung di bank.

\section{DAFTAR PUSTAKA}

BI. 2016. Laporan Perekonomian Indonesia 2015. Bank Indonesia. Jakarta.

Dewandini, S.R.K. 2010. Motivasi Petani Dalam Budidayatanaman Mendong (Fimbristylis globulosa) Di 
Rum Van Royensyah \& Yunita, Motivasi pengrajin industri...

Kecamatan Minggir Kabupaten Sleman. Skripsi. Fakultas Pertanian UNS. Surakarta.

Disparindagkop HSU. 2015. Laporan Tahunan. Dinas Perindustrian,
Perdagangan dan Koperasi Kab. HSU. Amuntai

Tohar, M. Membuka Usaha Kecil. 2000. Kanisius (Anggota IKAPI). Yogyakarta. 